\title{
Reflection on the Quality of Teacher Education Professional Thinking as Reflected by Pre-Service Teachers
}

\author{
Jacob M Selesho \\ Faculty of Management Sciences, Vaal University Technology, \\ Vanderbijlpark. South Africa \\ E-mail:jmselesho@webmail.co.za.za
}

\section{Doi:10.5901/mjss.2014.v5n2p57}

\section{Abstract}

Reflection is a mysterious concept to many of the students who enter the pre-service teacher educator programme. The study of exploring the quality of pre-service teacher education programme of a newly qualified educators have not been undertaken in our context, many have not written or even thought reflectively during early years of their career. This paper reports on the findings of a research conducted on the quality of teacher education programme for pre-service students who enrolled for the teacher programme. The key issue examined in the paper was to establish the quality of pre-service teacher programme and whether these programme has indeed produced students that have a significant contribution to the world of work. The assumption made is that pre-service teacher who have performed better in high school are likely to complete their qualification in the designated time at the university and perform better in the workplace. In an effort to widen understanding regarding the factors that predict the performance of a pre-service teacher at work, prior academic achievement results in the form of university results were examined. 228 student admitted in the pre-service qualification programme at the beginning of 2004 academic year were sampled for the study. Data concerning completion rate, satisfaction with the experiental learning, self inquiry, professional inquiry, professional training and mentoring progress were assessed. The survey were designed to study reflections of respondents related to the quality of their education courses and understanding of different educational phenomena with a purpose of studying changes in their pedagogical thinking. Data about career development were obtained from interviews with graduates, School Management Teams and learning facilitators. An analysis of the results revealed significant differences in the professional thinking of the educator readiness of co-operation with colleagues, in the perception of learners' characteristics and problems of teaching, and in the attitudes towards learners. The results reveal that pre-service teacher perfomance at university had a significant effect on world of work. High perfomance is associated with significantly less time before graduation, better career progression and better productivity in the teaching subjects. Gender differences were found in the study duration and career progress. Female students graduate earlier and have a better chance of climbing the ladder in terms of career progress.

Keywords: Reflection, professional thinking, pre-service

\section{Introduction}

Reflective teaching means looking at what you do in the classroom, thinking about why you do it, and thinking about if it works - a process of self-observation and self-evaluation. By collecting information about what goes on in our classroom, and by analyzing and evaluating this information, we identify and explore our own practices and underlying beliefs (Gibbs, 1998). This may then lead to changes and improvements in our teaching. Reflective teaching involves recognizing, examining, ruminating over the way an individual teaches. As individuals possess their own background and experience, bring certain beliefs, assumptions, knowledge, attitudes and values to teaching (Liberman \& Miller, 1999).

In the last few years there has been competing contextual views with regard to the effectiveness and efficiency of young professional in South Africa. These competing views have pitted against the teachers ability to teaching effectively and their professiona ability to think critically. In the teacher education curriculum critical thinking was implemented as part of the professional development. If students teachers are to undertake teaching practice they should be in the possession to give their critical responses in so far as their training is concerned. The differing opinion has ignited reflection on the progressive transformative for teacher education pattern.

However, new graduate teachers may not be familiar with how to conduct critical analysis activities in their diferent specialisation due to the limited pedagogical guidance. In the classroom context, narrative analysis activities, one of the types of critical analysis activities, have been used to engage students to analyse their learning (Anderson, 2008). 
Developing critical thinking skills in societal contexts involved examining "the deep meanings, personal implications, and social consequences of any knowledge, theme, technique, text or material" (Lip 2010: 550). It seemed that students develop critical thinking skills if they could interpret the underlying messages from any text such as their learning experience through micro teaching. From their personal and social perspectives which can be derived from or related to their experiences in their daily lives. Critical thinking was also seen as a combination of knowledge, attitudes, and skills, and understanding situations, evaluating different points of views and solving problems.

As Elbaz (1992) this study was guided by Scriven and Paul's (2003) definition of critical -thinking to blend with film study, as the definition was clear, concise and comprehensive. Critical thinking skills is the intellectually disciplined process of actively and skilfully conceptualizing, applying, analyzing, synthesizing, and/or evaluating information, or generated by observation, experience, reflection, reasoning or communication, as a guide to belief and action from film (Elbaz, 1992).

Researchers have used critical analysis activities with film to improve their students' critical thinking skills, which were most commonly used for analyzing the narrative, cultural, cinematic or rhetorical aspects of film (Franselow, 1997). However, the distinctions of these critical analysis activities with film have not been defined clearly by a number of researchers (Gibbs, 1988) and even in the English language curriculum. Anderson (2008), however, has done a better job defining the activities. She differentiated the definitions of these critical analysis activities into four types of analysis; she has also provided examples of pedagogical practices of implementing these critical analysis activities which would provide Hong Kong English teachers with a very clear pedagogical model of engaging students to analyze film from different critical perspectives. Anderson (2008) defined these critical analysis activities for film study as applications to analyzing film as a literacy text which have been used by writing teachers of secondary and first year university students in their writing classes (Fanselow, 1997; Freeman, 1992. Freeman, 1996; Freeman \& Richards, 1993).

An important part of teacher identity has to do with capacity feelings or the sense that she or he is competent in the job. The degree to which a teacher feels personally efficacious is also the degree to which she or he becomes a conscious agent in educational contexts, with strength to alter and improve them. A heightened sense of efficacy is of help when teachers are faced with demands to implement new methods as these are taken as challenges rather than burdens (van den Berg 2002 cited by Vandeyar, 2005). A low sense of efficacy, in turn, will affect the mode of responding to new situations, including difficult or unmotivated students. Both self-efficacy and agency operate in interaction with the possibilities offered by social structures such as the school environment, or change demands produced extraneously. If these conditions clash with what teachers believe they can do or believe should be done, they may result in passive submission (lack of motivation) or in reasonable attempts to implement without leaving aside those practices already considered sound (Vandeyar 2005)

\section{Developing Critical Thinkers}

But critical thinking is an activity that can be observed in settings and domains very far removed from the school or college classroom. Indeed, there is no clear evidence that any of the skills of critical thinking learned in schools and colleges have much transferability to the contexts of adult life. Chemot 1995 cited Sternberg (1985) points out the lack of correspondence between what is required for critical thinking in adulthood and what is taught in school programs intended to develop critical thinking. He writes that "the problems of thinking in the real world do not correspond well with the problems of the large majority of programs that teach critical thinking. We are preparing students to deal with problems that are in many respects unlike those that they will face as adults" (Lip 2010, 194). In adulthood, we are thinking critically whenever we question why we, or our partners, behave in certain ways within relationships. Critical thinking is evident whenever employees question the appropriateness of a certain technique, mode of production, or organizational form.

\subsection{Critical thinking is a productive and positive activity}

Critical thinkers are actively engaged with life. They see themselves as creating and re-creating aspects of their personal, workplace, and political lives. They appreciate creativity, they are innovators, and they exude a sense that life is full of possibilities. Critical thinkers see the future as open and malleable, not as closed and fixed. They are selfconfident about their potential for changing aspects of their worlds, both as individuals and through collective action. Critical thinkers are sometimes portrayed as cynical people who often condemn the efforts of others without contributing anything themselves. Those who hold this view see being critical as somehow antisocial; it is seen as a belittling activity 
engaged in only by those with false assumptions of superiority. In fact, the opposite is true (Han, 1995).

Being critical thinkers entails a continual questioning of assumptions. People can never be in a state of complete critical development. If we ever felt that we had reached a state of fully developed or realized critical awareness, we would be contradicting one of the central tenets of critical thinking - namely, that we are skeptical of any claims to universal truth or total certainty. By its nature, critical thinking can never be finished in some final, static manner (Bailey \& Nunnan; 1996).

Critical thinking, critical analysis, critical awareness, critical consciousness, and critical reflection are exhortatory, heady, and often conveniently vague. We can justify almost any action with a learner, client, friend, or colleague by claiming that it assists the process of critical thinking. Central to developing critical thinkers must be some minimal level of consent on the part of those involved. Trying to force people to analyze critically the assumptions under which they have been thinking and living is likely to serve no function other than intimidating them to the point where resistance builds up against this process. We can, however, try to awaken, prompt, nurture, and encourage this process without making people feel threatened or patronized (Canning, 1991; Chamot, 1995).

An important part of teacher identity has to do with capacity feelings or the sense that she or he is competent in the job. The degree to which a teacher feels personally efficacious is also the degree to which she or he becomes a conscious agent in educational contexts, with strength to alter and improve them. A heightened sense of efficacy is of help when teachers are faced with demands to implement new methods as these are taken as challenges rather than burdens (van den Berg 2002). A low sense of efficacy, in turn, will affect the mode of responding to new situations, including difficult or unmotivated students. Both self-efficacy and agency operate in interaction with the possibilities offered by social structures such as the school environment, or change demands produced extraneously. If these conditions clash with what teachers believe they can do or believe should be done, they may result in passive submission (lack of motivation) or in reasonable attempts to implement without leaving aside those practices already considered sound (Vandeyar 2005)

\section{Methodology}

Data were collected from graduates of university from students enrolled for Teacher Education programmes. The population for the study were third year students enrolled for school experiences, 82 students were males while 146 were females.

\subsection{Procedure}

The graduation throughput database of 2013 was used as a correlation with Grade 12 results of 2008 when these students were admitted. The intention was to determine if there is any gap as a result of Grade 12 performances; these high quintile learners and their performance in four years. These correlations can be interpreted as indicators of the performance measurements towards completing the degree in four years.

Accordingly, we examined individual student Grade 12 results and developed Swedish ratings to determine their admission status and corresponding first-year results. This assisted in determining the predictive validity; the student teaching subject was also taken into consideration. The focus was on the student admitted in 2008 with the intention of graduating in 2013. Finally, we compared the graduation rates among males and females and the different programmes.

The researcher conducted surveys in order to gather qualitative and quantitative sources of data that would shed more light on this group of students admitted into teacher education programmes.

\section{Discussion and Findings}

Data on the specific critical thinking skills and abilities were selected and anlaysed as well as the educational support provided those student while they were at doing their practicals. Table 1 captures gender representatives.

Table 1: Gender representatives

\begin{tabular}{|c|c|c|c|c|c|c|}
\hline \multirow{2}{*}{ Gender of Students } & \multicolumn{2}{|c|}{ Male } & \multicolumn{2}{c|}{ Female } & \multicolumn{2}{c|}{ Total } \\
\cline { 2 - 7 } & $\mathbf{M}$ & $\%$ & $\mathbf{F}$ & $\%$ & $\mathbf{M}+\mathbf{F}$ & $\%$ \\
\hline Gender representatives & 82 & $35.96 \%$ & 146 & $64.01 \%$ & 228 & $100 \%$ \\
\hline Inadequate food & 38 & 30.89 & 31 & 58.49 & 157 & 36.86 \\
\hline
\end{tabular}


Table 2 shows that the majority of the respondents were female (64.01\%) as compared to the male students participation $(35.96 \%)$ and this patterns runs across six professioal qualifications. The gender issues did also play an important role when considering the learning that takes place into this programme. While focusing on the learning that takes place during the practicals the study can reveal that there was differences with regards to the acceptance and implementation of instruction between male student and their female counterparts.

\subsection{Profesional Support afforded during the parcticals}

Data were sought the from six groups representing all qualifications on the specific forms of educational support programmes which were implemented by each sampled organisation while attending to their practicals sessions.

Table 2: Professional Support

\begin{tabular}{|l|c|c|c|c|}
\hline \multirow{2}{*}{ Professional Support } & \multicolumn{2}{|c|}{ Male (N= 82) } & \multicolumn{2}{c|}{ Female (N= 146) } \\
\cline { 2 - 5 } & No (M) & Yes (F) & No (F) & Yes (F) \\
\hline Satisfied with TP expectations & $33(40.2 \%)$ & $49(59.7 \%)$ & $53(36.3 \%)$ & $93(63.6 \%)$ \\
\hline Satisfied with professional training & $23(28.0 \%)$ & $59(71.9 \%)$ & $18(12.3 \%)$ & $128(87.6 \%)$ \\
\hline Satisfied with the self-inquiry & $8(9.7 \%)$ & $74(90.2 \%)$ & $15(10.2 \%)$ & $131(89.7 \%)$ \\
\hline
\end{tabular}

Table 3 shows that there was concurrence among the six groups of participants students that the educational support provided to the students while on the practical is lacking to particular. The data reflect that in most cases female student teachers score higher that their male counterpart with regard to the skills gained while at the practicals. The data also shows that the gender differences among the male and females corroborated each other's evidence that the institutions did prepared them fairly in the three factors being assessed above. The conflicting data from the student only comes to the number of student agreein with the factors as compared to the disagreeing students, this clearly demostrate that either they did not focus their response in line with the expectation, $87.6 \%$ of yes from the female student with regard to their professional as compared to $71.9 \%$ of male clearly demostrates that the student were prepared thorough to undertake the process.

Table 3: Forms of educational support

\begin{tabular}{|l|c|c|c|c|}
\hline \multirow{2}{*}{ Form Educational Support } & \multicolumn{2}{|c|}{ Male (N = 82) } & \multicolumn{2}{c|}{ Female (N = 6) } \\
\cline { 2 - 5 } & No (F) & Yes (F) & No (F) & Yes (F) \\
\hline Relationship with mentor teachers & $5 \%$ & $95 \%$ & 0 & $100 \%$ \\
\hline Knowledge application & $46(86.79)$ & $7(13.21)$ & $4(66.67)$ & $2(33.33)$ \\
\hline
\end{tabular}

Table 3 above shows that the mentors were not convienced that some of the students are in the right career paths, student were not adhering to the deadline as well as the profesional code of conduct. In some cases the student will absent themselves from schools without the mentor prior approval or indication for that matter. While, $73 \%$ of the mentor were of the opinion that students did not have the ability to apply the theoretical knowledge learned through in the daily activities. Although students have extensive theoretical knowledge there was little evidence on how the student apply this knowledge in their daily routine.

\section{Conclusion}

Experienced teachers and teacher educators are aware that becoming a teacher is an ongoing, life-long process. Johnson (2006: 239) argues that the process of learning to teach is 'socially negotiated and contingent on knowledge of self, students, subject matter, curricula, and setting'. The most influential experiences for any student teacher are their ability to reflect critically during their practice. One of the most influential experiences in developing a deeper understanding of this knowledge base is the Teaching practice a well-thought-of, user-friendly resource for pre-service teachers and practicum instructors to use while participating in a teaching practicum, especially one that fosters observations and reflection. In promoting a reflective approach, the authors draw on current research in order to bring together a variety of topics that will engage pre-service teachers in thoughtful evaluations about what to expect during the 
teaching practicum and how to maximize the learning experience.

\section{References}

Bailey, K. M., \& Nunan, D. (Eds.) 1996. Voices from the language classroom: Qualitative research in second language education. Cambridge: Cambridge University Press.

Bartlett, L. 1990. Teacher development through reflective teaching. In J.C. Richards and D. Nunan (eds.), Second language teacher education. Cambridge: Cambridge University Press.

Canning, C. 1991."What teachers Say About Reflection", article published by the University of Northern lowa.

Chamot, A. U. 1995. The teacher's voice: Action research in your classroom. ERIC/CLNews Bulletin 18(2), 1, 5-8.

Clarke,R., Croft, P. 1998. Critical Reading for the Reflective Practitioner. Butterworth Heineman, Oxford.

Edge, J., \& Richards, K. (Eds.). 1993. Teachers develop teachers research: Papers on classroom research and teacher development. Oxford: Heineman International.

Elbaz, F. 1992. Teacher thinking: A study of practical knowledge. New York: Nichols Publishing.

Fanselow, J. 1997. Post card realities. In C. P. Casanave \& S. R. Schechter (Eds.), On becoming a language teacher (pp. 157-172). Hillsdale, NJ: Lawrence Erlbaum.

Freeman, D. 1992. Language teacher education, emerging discourse, and change in classroom practice. In J. Flowerdew, M. Brock, \& S. Hsia (Eds.), Perspectives on language teacher education (pp. 1-21). Hong Kong: City Polytechnic of Hong Kong

Freeman, D. 1996. Redefining the relationship between research and what teachers know. In K. M. Bailey \& D. Nunan (Eds.), Voices from the language classroom: Qualitative research in second language education (pp. 88-115). Cambridge: Cambridge University Press.

Freeman, D., \& Richards, C. 1993. Conceptions of teaching and the education of second language teachers. TESOL Quarterly 17(2), 193-216

Gibbs, G. 1988 Learning by Doing: A guide to teaching and learning methods. FurtherEducation Unit, Oxford Brookes University, Oxford.

Han, C. 1995. Issues in education, Reflection is essential in teacher education, Childwood education, 71, 228-230.

Jasper, M.A. 1999. Nurses' perceptions of the value of written reflection, Nurse Education Today, vol 19, issue 6, pp 452-463.

Kemmis, S. 1985. 'Action Research and the Politics of Reflection', Chapter 10 in Boud, D., Keogh., and Walker, D. (eds) Reflection: Turning experience into learning, Kogan Page.

Kemmis, S., \& McTaggart, R. (1982). The action research planner. Victoria: Deakin University Press.

LiebermanA. \& Miller, L. 1999. Teachers - Transforming their world and their work. New York: Teachers College Press.Little, J. Inside teacher community: Representations of classroom practice. Teachers College Record, 105(6), 913-945.

Paul Chi-Hong Lip 2010. Investigating Form 6 students' development on their critical thinking skills with narrative analysis activities with film: A case study of a Hong Kong language classroomCaritas Institute for Further \& Adult Education-Kowloon. Few The AsiaPacific Education Researcher 19:(3), pp. 549-558.

Schön, D.A. (Ed.). 1993. The reflective turn: Case studies in and on educational practice. New York: Teachers College Press.

Vandeyar, S. (2005) Conflicting demands: Assessment practices in three South African primary schools undergoing desegregation. Curriculum Inquiry 35, 4,461-481. 
